\title{
An overview of molecular identification of insect fauna with special emphasis on chalcid wasps (Hymenoptera: Chalcidoidea) of India
}

\author{
Ajaz RASOOL ${ }^{1}$, Tariq AHMAD**1, Bashir Ahmad GANAI ${ }^{2}$, Shaziya GULL ${ }^{1}$
}

Received November 21, 2017; accepted March 31, 2018.

Delo je prispelo 21. novembra 2017, sprejeto 31. marca 2018.

\begin{abstract}
Identifying organisms has grown in importance as we monitor the biological effects of global climate change and attempt to preserve species diversity in the face of accelerating habitat destruction. Classical taxonomy falls short in this race to catalogue biological diversity before it disappears. Differentiating subtle anatomical differences between closely related species requires the subjective judgment of highly trained specialists - and few are being trained in institutes today. DNA barcodes allow non-experts to objectively identify species - from small, damaged, or even industrially processed material. The aim of DNA barcoding is to establish a shared community resource of DNA sequences commonly used for identification, discrimination or taxonomic classification of organisms. It is a method that uses a short genetic marker in an organism's DNA to identify and distinguish its belonging from particular species, varieties or inter varieties. This simple technique has attracted attention from taxonomists, ecologists, conservation biologists, agriculturists, plant-quarantine officers and studies using the DNA barcode has rapidly increased. The extreme diversity of insects and their economical, epidemiological and agricultural importance have made them a major target of DNA barcoding. In this review, we present an overview of DNA barcoding of insects with emphasis on Chalcid wasps of India.
\end{abstract}

Key words: biological diversity; catalogue; chalcid wasps; classical taxonomy, DNA barcode; DNA sequence, genetic marker
IZVLEČEK

\author{
PREGLED MOLEKULARNEGA DOLOČANJA \\ ŽUŽELK V INDIJI S POUDARKOM NA OSICAH \\ NAJEZDNICAH (Hymenoptera: Chalcidoidea)
}

Določanje organizmov pridobiva na pomenu pri spremljanju globalnih podnebnih sprememb in pri poskusih ohranjanja biodiverzitete $\mathrm{v}$ procesu hitrega uničevanja habitatov. Klasična taksonomija $\mathrm{v}$ teh procesih ne uspe določiti vse biodiverzitete pred njenim propadom. Prepoznavanje majhnih anatomskih razlik med ozko sorodnimi vrstami zahteva presojo visoko usposobljenih specialistov, ki jih je danes vedno manj. Vrednotenje DNK zaporedij omogoča tudi nestrokovnjakom objektivno prepoznavanje vrst kot tudi njihovih malih ali poškodovanih ostankov ali celo industrijsko predelanih materialov. Namen te metode je ustvariti nabor DNK zaporedij za vzajemno rabo pri določanju in taksonomskem razvrščanju organizmov poznano tudi pod imenom DNK črtne kode. Pri tej metodi omogoča kratek genetski marker v DNK organizma njegovo določitev in razlikovanje od drugih vrst, različic. Ta preprosta tehnika je pritegnila pozornost taksonomov, ekologov, konzervatorskih biologov, agronomov, fitokarantenskih uradnikov in preučevanje na osnovi sekvenciranja DNK je hitro poraslo. Izjemna raznolikost žuželk in njihov ekonomski, epidemiološki in kmetijski pomen so jih naredile za tarčno skupino preučevanj na osnovi DNK črtnih kod. V tem sestavku predstavljamo pregled analiz z DNK črtnimi kodami žuželk s poudarkom na osicah najezdnicah iz Indije.

Ključne besede: biodiverziteta; seznam; osice najezdnice; klasična taksonomija; genetska koda; DNK zaporedje; genetski marker

\section{INTRODUCTION}

Chalcid wasps are one of the most diverse groups of insects numerically, structurally, and biologically belonging to the superfamily Chalcidoidea and order Hymenoptera. With about 150,000 described species, the Hymenoptera is the fourth largest insect order after
Coleoptera, Lepidoptera, and Diptera (Grimaldi \& Engel, 2005; Beutel \& Pohl, 2006). With an estimated total diversity of some 22,500 known species and more than 500,000 morphologically distinct species (Munro et al., 2011) and an even larger number of cryptic

1 Entomology Research Laboratory, Post Graduate Department of Zoology, University of Kashmir, Srinagar, 190006, J \& K, India *Corresponding author: drtariqento@kashmiruniversity.ac.in

2 Centre of Research for Development (CORD), University of Kashmir, Srinagar, 190006, J\&K, India 
species possible, the Chalcidoidea superfamily is likely the most diverse group of insects in order Hymenoptera. Most Chalcid wasps are parasitoids attacking immature and adult stages of virtually all insect orders, mostly Hemiptera and Holometabola and hence are used as biological control agents of agricultural and ornamental pests thus having tremendous importance in both natural and managed ecosystems both economically and ecologically (Preethi et al., 2016).

Species identification is a fundamental part of recognizing and describing biodiversity in an ecosystem. Traditionally, identification has been based on morphological diagnoses provided by taxonomic studies. Only experts such as taxonomists and trained technicians can identify taxa accurately, because it requires special skills acquired through extensive experience. As interest in biodiversity has increased in the fields of ecology, evolutionary biology, agriculture and economics, among others, it has become increasingly important to precisely identify species. However, the number of taxonomists and other identification experts has drastically decreased. The characterization based on morphometric characters is not well suited for phylogeographical studies because both phenotypic plasticity and genetic variability in the characters employed for species recognition can lead to incorrect identifications (Pires \& Marinoni, 2010). It overlooks morphologically cryptic taxa, which are common in many groups (Jarman \& Elliott, 2000) and the use of keys often demands such a high level of expertise that misdiagnoses are common. Faunal and floral studies are besieged by specimens in immature stages that lack the characters necessary for identification, or sexes that cannot be matched, especially if they are dimorphic such as some insects in which the sexes vary dramatically in size or colour (Pinzón-Navarro et al., 2010).Consequently, alternative and accurate identification methods that non-experts can use are required.

One of the most promising approaches to revitalize traditional taxonomy and help it rise above the taxonomic crisis is the use of molecular data for identifying taxa, which has long been a fundamental idea of many biologists (Busse et al., 1996; Blaxter, 2004). This method has received increased acceptance because it is simple and affordable (Padial \& De La Riva, 2007). DNA barcoding promises the ability to automate the identification of specimens by determining the sequence of the barcode region, avoiding the complexities inherent in morphological identifications, and prompting advocates arguing for the establishment of a system that ultimately might be applied to all life (Tautz et al., 2003; Blaxter, 2004; Savolainen et al., 2005). Advances in DNA-sequencing technologies have enabled researchers studying biodiversity to conduct simple, cost-effective and rapid DNA analyses. This progress in biotechnology, and the taxonomy crisis itself, played a large role in the creation of DNA barcoding. DNA barcoding, in particular, was formally introduced more than a decade ago as an alternative way to assign species names to specimens, addressing concerns and limitations with traditional morphological identifications (Hebert et al., 2003). The use of DNA sequences to gain information about the taxonomic affinities of an unknown specimen saw its earliest adoption in the least morphologically amenable groups such as viruses and bacteria (Theron \& Cloete, 2000). More recently, it has been applied to plants (Chase et al., 2005), to simple metazoan animals such as nematode worms (Floyd et al., 2002) and even to fascinating mega fauna such as birds, fish, and mammals (Ward et al., 2005; Clare et al., 2007; Kerr et al., 2007). This approach relies on the use of algorithms enabling DNA-sequence comparison, such as Basic Local Alignment Search Tool (BLAST) (Altschul et al., 1990), in conjunction with DNA databases such as GenBank.

\subsection{DNA barcoding and taxonomy}

India is one of the mega biodiversity rich countries, home to hotspots like the Western Ghats and the Himalayas (ENVIS, 2011). In spite of this rich biodiversity heritage, well documented in the Fauna of British India volumes and having many endemics in all groups, much still remains to be understood about it. Many species are difficult to identify and are poorly known. Insects are the most abundant of all life forms on earth. India with about $2 \%$ of the global land area is among the top 20 mega biodiversity nations in the world accounting for $7.10 \%$ of the world insect fauna. It is estimated that over 900,000 species of insects are known across the globe with over 60,000 species described from India with nearly as many species yet to be named. However, the number of barcodes generated from India is $4.6 \%$ of known species, while the corresponding global scenario is about $16 \%$ of described species, and hence requires a lot of emphasis to catch up with the world scenario (Jalali et al., 2015).The first initiative in DNA barcoding was led by the Department of Biotechnology (DBT), India, to barcode species of butterflies and amphibians from the Western Ghats of India (Gaikward, 2014). To speed up taxonomic identification, DNA barcoding is now being considered as an alternative tool for insect biodiversity identification in India and the world.

Chalcid wasp species in India have been described and illustrated mostly at morphological level. Keeping in view various drawbacks of morphological taxonomy like lack of taxonomic experts, overlooking cryptic taxa, difficulty in using keys and due to phenotypic plasticity 
and genetic variability with changing environmental conditions as has been found in other animal species, alternative and complementary approach (molecular taxonomy) has been used in identification of specimens. Molecular approach to Chalcid identification provides a grim scenario from India with very little work done so far at molecular level. Recently Kumar et al., (2009), Jalali et al., (2015) and Venkatesan et al., (2016) have carried some research work at molecular level in Chalcid fauna and came out with some interesting results. The rDNA internal transcribed spacers region 2 (ITS-2) (Kumar et al., 2009), cytochrome c oxidase subunit 1 (COI), NADH dehydrogenase subunit 1 (nadh1), and cytochrome b (cytb) markers used in recent molecular analysis have significantly increased our understanding of the phylogenetic relationships between insect species. Kumar et al. (2009) used Internal transcribed spacer-2 restriction fragment length polymorphism (ITS-2-RFLP) tool to differentiate some exotic and indigenous Trichogrammatid egg parasitoids from India whereas Venkatesan et al. (2011) studied characterization and identification of Acerophagus papayae Noyes \& Schauff, 2003 (Hymenoptera: Encyrtidae), an introduced parasitoid of papaya mealybug, Paracoccus marginatus Williams \& Granara de Willink, 1992 through DNA barcoding. The study was undertaken for the DNA barcoding of A. papayae, using $\mathrm{CO} 1$ region in order to boost and confirm that the introduced and native populations in Pune belonged to the same species. In addition DNA Barcoding for Identification of Agriculturally Important Insects of India was recently carried out by Jalali et al., (2015). Different parasitoids, predators and other insects were collected from various cities of India and were used for DNA barcoding studies. The specimens, thus collected and morphologically identified, were used for COI barcoding at the National Bureau of Agriculturally Important Insects (NBAII) Bangalore, India. Venkatesan et al. (2016) carried out study to unravel the discrimination success in the two molecular marker loci cytochrome oxidase I (COI) and internal transcribed spacer-2 (ITS-2) region of Trichogrammatids.

\subsection{DNA barcoding of insect fauna}

DNA barcoding, a taxonomic method that uses a short, standardized DNA sequence to identify species, has gained increased attention and acceptance from members of the scientific community interested in documenting the Earths' biodiversity (Hebert et al., 2003; Savolainen et al., 2005; Hajibabaei et al., 2007; Borisenko et al., 2009; Ivanova et al., 2009). One of the advantages of DNA barcoding with respect to traditional taxonomy is the speed and low costs involved in assemblage and analyzing data (Borisenko et al., 2009; Strutzenberger et al., 2010). The creation of the CBOL's online database (The Barcode of Life Data System - BOLD: www.barcodinglife.org) has provided an impetus for numerous researchers to join the barcode initiative. It is easy to access and provides free storage and retrieval of molecular, morphological and geographical data, besides a built-in, integrated analysis tools such as tree reconstructions on the basis of genetic similarity (Ratnasingham \& Hebert, 2007; Frézal \& Leblois, 2008). DNA barcoding relies on the premises that the genetic variation among species is greater than the variation within species (Hajibabaei et al., 2007). Mitochondrial genes as universal markers were mostly driven by the fact that the mitochondria is maternally inherited, avoiding problems with recombination. Also, the mitochondrial genome has a high mutation rate when compared with the nuclear genome, which results in high degrees of intra-specific polymorphism and divergence, important in evolutionary studies (Williams \& Knowlton, 2001; Wheat \& Watt, 2008; Hlaing et al., 2009). Taxonomy and systematics of insects using DNA barcoding has been enriched with several contributions from various authors. Molecular studies in the order Hemiptera were carried out by Foottit et al. (2009), Lee et al. (2010) and Shufran \& Puterka (2011), whereas Smith et al. (2006), Ekrem et al. (2007) and Rivera \& Currie (2009) barcoded Diptera. Hymenoptera was enriched by contributions of Smith et al. (2005), Sheffield et al. (2009) and Smith et al. (2009) while Yoshitake et al. (2008), Raupach et al. (2010) and Greenstone et al. (2011) carried out studies in Coleoptera. Molecular studies in Trichoptera were performed by Salokannel et al. (2010), Geraci et al. (2011) and Zhou et al. (2011). Characteristics intrinsic to insects, such as their diversity, biological control and the economic and epidemiological relevance of some groups, have made them the main target of DNA barcoding studies. This standard database can be used in studies on the taxonomy, phylogeny, ecology, agriculture and conservation of various groups of organisms (Jinbo et al., 2011).Several contributions focusing on identification using the mitochondrial COI have proved useful in the detection of cryptic insect species. Some of those cryptic species which were initially almost impossible to separate using morphological characters alone, have had their identities corroborated by other characters in their natural history and even characters in their morphology (Hebert et al., 2004; Smith et al., 2006; Pfenninger et al., 2007; Decaëns \& Rougerie, 2008; Vaglia et al., 2008; Wheat \& Watt, 2008; Dasmahapatra et al., 2010; Hausmann et al., 2011. Morphological differences, cases of sexual dimorphism, different castes, or different stages of development have made barcode sequences applicative (Miller et al., 2005; Geraci et al., 2011); Jinbo et al., 2011). Other applications include : identification of host plants by sequencing the stomach contents or plant tissues left on the outside of an insect's body (JuradoRivera et al., 2009); identification of the stomach contents of predators in biological control studies 
(Greenstone et al., 2005); Greenstone (2006); additional data uncovering trophic relationships (Clare et al., 2009; Hrcek et al., 2011); and finally, population genetics, community ecology and biodiversity inventories (Hajibabaei et al., 2006; Lukhtanov et al., 2009; Craft et al., 2010).

\subsection{Limitations of DNA barcoding}

DNA barcoding has its pitfalls too. Its success is dependent on the strength of the pretension that interspecific variation exceeds intraspecific variation by one order of magnitude, thus establishing a "barcoding gap", or on the reciprocal monophyly of species (Wiemers \& Fiedler (2007). The presence of multiple mitochondrial gene haplotypes, such as nuclear pseudogenes of the mitochondria genome (NUMT) or heteroplasmy also reduces the validity of DNA barcoding. This problem has been reported for many insects (Gellissen \& Michaelis, 1987; Zhang \& Hewitt,
1996; Bensasson et al., 2000; Brower, 2006; Rubinoff et al., 2006) and can also affect the barcoding results (Song et al., 2008).

\subsection{Summary from barcode of life data system}

Barcode of Life Data Systems (commonly known as BOLD) is a sequence database specifically devoted to DNA barcoding. It provides an online platform for analyzing DNA sequences. BOLD is populated with nearly 163617 insect species barcodes out of which India has only 3694 barcodes. There are about 5448764 records of specimens of insects in BOLD statistics with 4404476 specimens with sequences and 4092095 specimens with Barcodes. It represents 218968 species in which 170452 have been barcoded (Fig. 1). As far as hymenoptera are concerned there are 907902 specimen records with 666323 specimens with sequences. 563353 specimens are with barcodes representing 35907 species with 26017 species barcoded (BOLD v4) (Fig. 1).
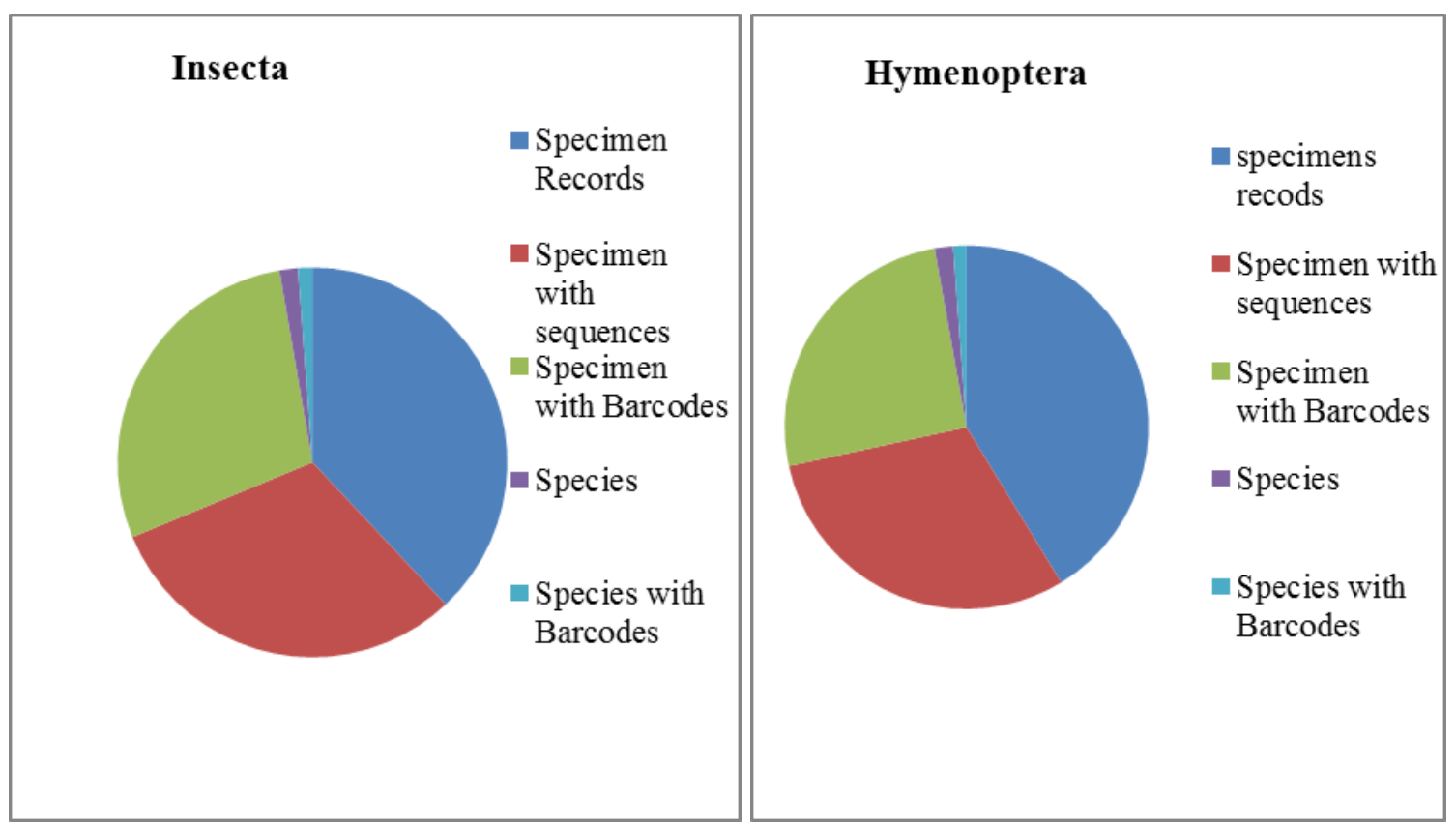

Figure 1: Barcoding status of Insecta (left) and Hymenoptera (right) in BOLD. (Data accessed on 30 July 2017)

\subsection{DNA barcoding status of Chalcidoidea in India}

An estimated 150000 Hymenopteran species of insects are reported worldwide of which 25169 species have been barcoded (Axel et al., 2013) (Fig. 2). In India, little work has been done so far at molecular level. With an estimated 10000 species, only 167 species of Hymenoptera have been subjected to barcoding in the Insect Barcode Informatica (IBIn): a platform to assist and manage acquisition, storage, analysis and to explore DNA barcode records for species identification and genetic analysis of status data of Indian insects (Fig. 2). Out of 167 hymenopteran species barcoded, 58 belong to superfamily Chalcidoidea including 44 Trichogrammatidae, 5 Eulophidae, 2 Torymidae and 7 Encyrtidae species (Fig. 3). 
An overview of molecular identification of insect ... on chalcid wasps (Hymenoptera: Chalcidoidea) of India

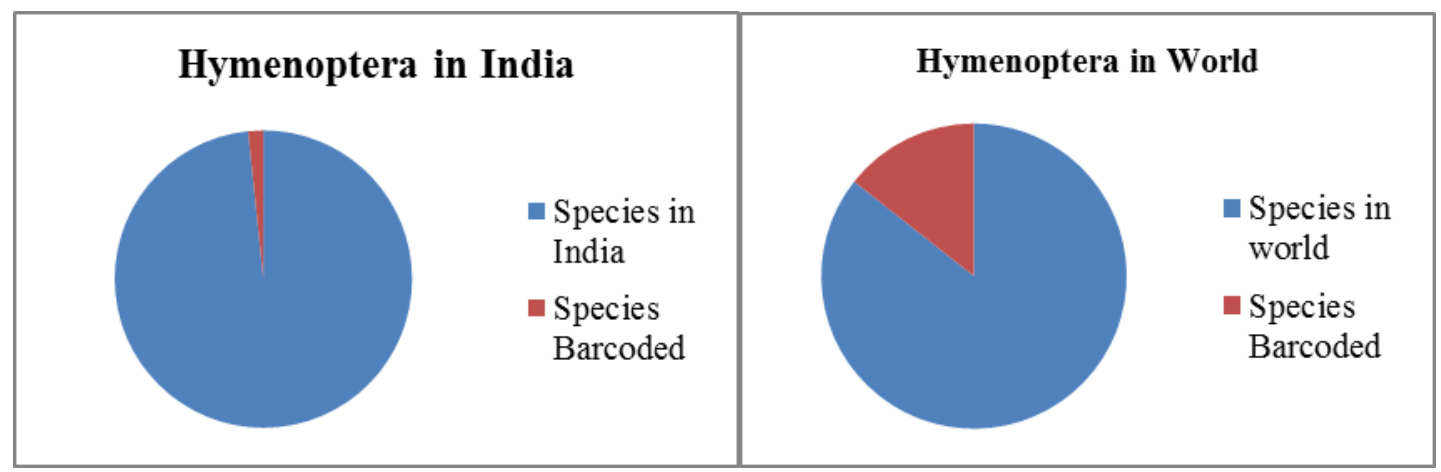

Figure 2: Hymenoptera: species and barcodes in the India (left) and in World (right) (Data accessed on 30 July 2017)

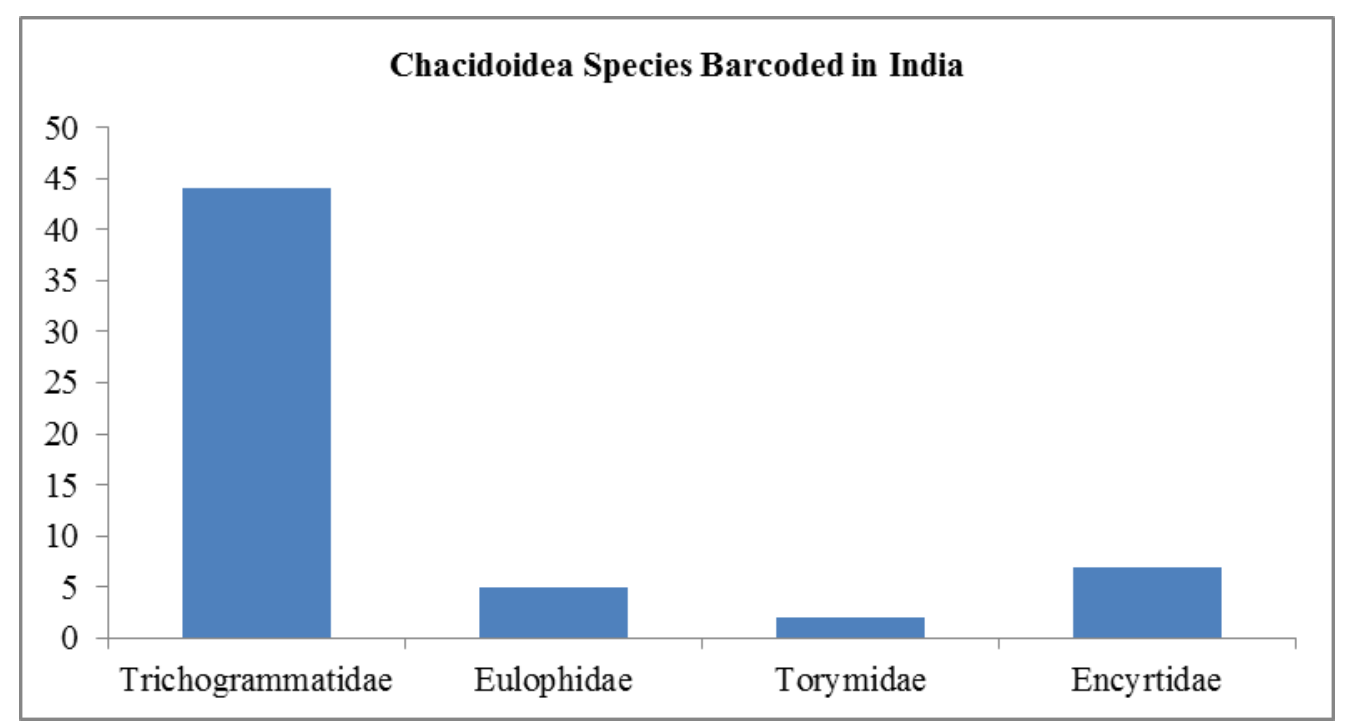

Figure 3: Number of chalcid wasps barcoded in India (Data accessed on 30 July 2017)

At global level an estimated 25169 Hymenopteran species have been barcoded so far among 150000 described species (Axel et al., 2013). Species of Chalcidoidea are richly represented among the species barcoded so far in the order Hymenoptera. Out of 38287 Specimens of Chalcid wasps with barcodes, only $3.6 \%$
(1382) of species with barcodes are represented in Barcode of Life Data system (BOLD) with Eulophidae most represented (357) and Mymarommatidae and Rotoitidae least represented with just one species. Records of individual families of superfamily Chalcidoidea in BOLD are shown in Table 1. 
Ajaz RASOOL et al.

Table 1: Current summary of DNA barcoding library of Chalcidoidea in the BOLD system

\begin{tabular}{|c|c|c|c|c|c|c|}
\hline Sr. No. & Family & $\begin{array}{l}\text { Specimen } \\
\text { records }\end{array}$ & $\begin{array}{l}\text { Specimen } \\
\text { with } \\
\text { sequences }\end{array}$ & $\begin{array}{l}\text { Specimen } \\
\text { With } \\
\text { Barcodes }\end{array}$ & Species & $\begin{array}{l}\text { Species with } \\
\text { Barcodes }\end{array}$ \\
\hline 1 & Agonidae & 2410 & 2324 & 1569 & 372 & 271 \\
\hline 2 & Aphelinidae & 7892 & $6803 \mathrm{~s}$ & 2875 & 56 & 47 \\
\hline 3 & Chalcididae & 2493 & 1163 & 611 & 175 & 88 \\
\hline 4 & Encyrtidae & 4622 & 4139 & 1799 & 92 & 66 \\
\hline 5 & Eulophidae & 21321 & 18444 & 11574 & 642 & 357 \\
\hline 6 & Eucharitidae & 241 & 147 & 81 & 44 & 29 \\
\hline 7 & Eupelmidae & 1749 & 1190 & 700 & 126 & 58 \\
\hline 8 & Eurytomidae & 3029 & 2474 & 1287 & 90 & 45 \\
\hline 9 & Leucospidae & 80 & 34 & 09 & 14 & 06 \\
\hline 10 & Mymaridae & 20379 & 18629 & 6637 & 61 & 27 \\
\hline 11 & Mymarommatidae & 56 & 07 & 04 & 01 & 01 \\
\hline 12 & Ormyridae & 278 & 223 & 159 & 22 & 12 \\
\hline 13 & Perilampidae & 1211 & 784 & 543 & 87 & 58 \\
\hline 14 & Pteromalidae & 13114 & 10946 & 6830 & 547 & 227 \\
\hline 15 & Rotoitidae & 01 & 01 & 01 & 01 & 01 \\
\hline 16 & Signiphoridae & 168 & 163 & 85 & 01 & 00 \\
\hline 17 & Tanaostigmatidae & 36 & 15 & 05 & 07 & 04 \\
\hline 18 & Tetracampidae & 21 & 17 & 14 & 07 & 05 \\
\hline 19 & Torymidae & 2420 & 1999 & 1056 & 97 & 53 \\
\hline 20 & Trichogrammatidae & 5707 & 5356 & 2448 & 31 & 27 \\
\hline
\end{tabular}

(Data Accessed on 30 July 2017) 


\section{CONCLUSIONS}

Species identification is a fundamental part of recognizing and describing biodiversity. Traditionally, identification has been based on morphological diagnoses provided by taxonomic studies. The classical use of morphological trait for species identification has several limitations and requires a high level of expertise for correct identification of species. The DNA barcoding approach might correctly present the best solution for identifying species when their morphology is of limited use (Hebert et al., 2003). DNA barcoding has recently picked up pace in India and helped in the unambiguous identification of insect species of India including Chalcid wasps. This latest method of species identification through DNA barcoding of mitochondrial cytochrome oxidase gene I (COI) (Hebert et al., 2003) clearly gives support to improve classifications and examine the precision of morphological traits commonly used in taxonomy critically.

\section{ACKNOWLEDGMENT}

The authors are highly grateful to the Prof. Fayaz Ahmad, Head of Zoology Department, University of Kashmir for providing working facilities. We are also thankful to Dr. Abdul Ahad Buhroo, Associate Professor, University of Kashmir for necessary guidelines and follow-up.

\section{REFERENCES}

Altschul, S.F., Gish, W., Miller, W.E., Myers, W., \& Lipman, D. J. (1990). Basic local alignment search tool. Journal of Molecular Biology, 215, 403-410. https://doi.org/10.1016/S0022-2836(05)80360-2

Axel, J., Seraina, K., Lars, V., Heraty, J.M., Sharkey, M., \& Fredrik, R. (2013). "The Hymenopteran Tree of Life: Evidence from Protein-Coding Genes and Objectively Aligned Ribosomal Data". PLoS ONE, $8(8)$, e69344. https://doi.org/10.1371/journal.pone.0069344

Bensasson, D., Zhang, D. X., \& Hewitt, G. M. (2000). Frequent assimilation of mitochondrial DNA by grasshopper nuclear genomes. Molecular Biology and Evolution, 17(3), 406-415. https://doi.org/10.1093/oxfordjournals.molbev.a026 320

Beutel, R.G., \& Pohl, H. (2006). Endopterygote systematic- where do we stand and what is the goal(Hexapoda: Arthropoda). Systematic Entomology, 202-219. https://doi.org/10.1111/j.1365-3113.2006.00341.x

Blaxter, M.L. (2004). The promise of DNA taxonomy. Philosophical Transactions of the Royal Society London B, 359, 669-679. https://doi.org/10.1098/rstb.2003.1447

Brower, A. V. (2006). Problems with DNA barcodes for species delimitation:'ten species' of Astraptes fulgerator reassessed (Lepidoptera: Hesperiidae). Systematics and Biodiversity, 4(2), 127-132.

https://doi.org/10.1017/S147720000500191X
Busse, H.J., Denner, E.B.M., \& Lubitz, W. (1996). "Classification and identification of bacteria: Current approaches to an old problem. Overview of methods used in bacterial systematic." Journal of Biotechnology, $47, \quad 3-38$. https://doi.org/10.1016/0168-1656(96)01379-X

Chase, M.W., Salamin, N., Wilkinson, M., Dunwell, J.M., Kesanakurthi, R.P., Haidar, N., \& Savolainen, V. (2005). Land plants and DNA barcodes: shortterm and long-term goals. Philosophical Transactions of the Royal Society B. Biological Sciences, $\quad 360, \quad 1889-1895$. https://doi.org/10.1098/rstb.2005.1720

Clare, E.L., Lim, B.K., Engstrom, M.D., Eger, J.L., \& Hebert, P.D.N. (2007). DNA barcoding of Neotropical bats: species identification and discovery within Guyana. Molecular Ecology Notes, 7, 184-190. https://doi.org/10.1111/j.14718286.2006.01657.x

Clare, E.L., Fraser, E.E., Braid, H.E., Fenton, M.B., \& Hebert, P.D.N. (2009). Species on the menu of a generalist predator, the eastern red bat (Lasiurus borealis) - using a molecular approach to detect arthropod prey. Molecular Ecology, 18, 2532-2542. https://doi.org/10.1111/j.1365-294X.2009.04184.x

Craft, K.J., Pauls, S.U., Darrow, K., Miller, S.E., Hebert, P.D.N., Helgen, L. E., Novotny, V., \& Weiblen, G.D. (2010). Population genetics of ecological communities with DNA barcodes: an example from New Guinea Lepidoptera. Proceedings of the National Academy of Science, 11, 5041-5046. https://doi.org/10.1073/pnas.0913084107

Acta agriculturae Slovenica, 111 - 1, marec 2018 
Dasmahapatra, K.K., Elias, M., Hill, R.I., Hoffman, J.I., \& Mallet, J. (2010) Mitochondrial DNA barcoding detects some species that are real, and some that are not. Molecular Ecology Resources, 10, 264-273. https://doi.org/10.1111/j.1755-0998.2009.02763.x

Decaëns, T., \& Rougerie, R. (2008). Descriptions of two new species of Hemileucinae (Lepidoptera: Saturniidae) from the region of Muzo in Colombia evidence from morphology and DNA barcodes. Zootaxa, 1944, 34-52.

Ekrem, T., Willassen, E., \& Stur, E. (2007). A comprehensive DNA sequence library is essential for identification with DNA barcodes. Molecular Phylogenetics and Evolution, 43, 530542. https://doi.org/10.1016/j.ympev.2006.11.021

ENVIS (2011) - Centre on Floral Diversity, Ministry of Environment, Forest \& Climate Change, Governement of India, (accessed on 30 July 2017).

Floyd, R., Abebe, E., Papert, A., \& Blaxter, M. (2002). Molecular barcodes for soil nematode identification. Molecular Ecology, 11, 839-850. https://doi.org/10.1046/j.1365-294X.2002.01485.x

Foottit, R.G., Maw, H.E.L., Havill, N.P., Ahern, R.G., \& Montgomery, E. (2009). DNA barcodes to identify species and explore diversity in the Adelgidae (Insecta: Hemiptera: Aphidoidea). Molecular Ecology Resource, 9, 188-195. https://doi.org/10.1111/j.1755-0998.2009.02644.x

Frézal, L., \& Leblois, R. (2009). Four years of DNA barcoding: Current advances and prospects. Infection, Genetics and Evolution, 8, 727-736. https://doi.org/10.1016/j.meegid.2008.05.005

Gaikward, S. (2014). DNA Barcoding: The Indian Scenario. Barcode Bulletin, International Barcode of life, 5(4). Available from http://ibol.org/

Gellissen, G., \& Michaelis, G. (1987). Gene Transfer. Annals of the New York Academy of Sciences, 503(1), 391-401. https://doi.org/10.1111/j.1749-6632.1987.tb40625.X

Geraci, C.J., Mohammed, A.A., \& Zhou, X. (2011). DNA barcoding facilitates description of unknown faunas: a case study on Trichoptera in the headwaters of the Tigris River, Iraq. Journal of the North American Benthological Society, 30, 163173. https://doi.org/10.1899/10-011.1

Greenstone, M.H. (2006). Molecular methods for assessing insect parasitism. Bulletin of entomological research, 96, 1-13. Available from https://doi.org/10.1079/BER2005402

Greenstone, M.H., Rowley, D.L., Heimbach, U., Lundgren, G., Pfannenstiel, R.S., \& Rehner, S.A.
(2005). Barcoding generalist predators by polymerase chain reaction: carabids and spiders. Molecular Ecology, 14, 3247-3266. https://doi.org/10.1111/j.1365-294X.2005.02628.x

Greenstone, M.H., Vandenberg, N.J., \& Hu, J.H. (2011). Barcode haplotype variation in north American agroecosystem lady beetles (Coleoptera: Coccinellidae). Molecular Ecological Resources, 11 , 629-637. https://doi.org/10.1111/j.17550998.2011.03007.x

Grimaldi, D.A., \& Engel M.S. (2005). Evolution of the Insects. Cambridge University Press, Cambridge.

Hajibabaei, M., Janzen, D.H., Burns, J.M., Hallwachs, W., \& Hebert, P.D.N. (2006). DNA barcodes distinguish species of tropical Lepidoptera. Proceedings of the National Academy of Sciences, USA, 103, 968-971. https://doi.org/10.1073/pnas.0510466103

Hajibabaei, M., Singer, G.A.C., Hebert, P.D.N., \& Hickey, D.A. (2007). DNA barcoding: how it complements taxonomy, molecular phylogenetics and population genetics. TRENDS in Genetics, 23, 167-172. https://doi.org/10.1016/j.tig.2007.02.001

Hausmann, A., Haszprunar, G., \& Hebert, P.D.N. (2011). DNA Barcoding the Geometrid Fauna of Bavaria (Lepidoptera): Successes, Surprises, and Questions. PLoS ONE, 6, e17134. https://doi.org/10.1371/journal.pone.0017134

Hebert, P.D.N., Cywinska, A., Ball, S.L., \& DeWaard, J.R. (2003). Biological Identification through DNABarcodes. Proceedings of the Royal Society of London B: Biological Sciences, 270, 313-321. https://doi.org/10.1098/rspb.2002.2218

Hebert, P.D.N., Penton, E.H., Burns, J.M., Janzen, D.H., \& Hallwachs, W. (2004). Ten species in one: DNA barcoding reveals cryptic species in the neotropical skipper butterfly Astraptes fulgerator. Proceedings of the National Academy of Sciences, USA, 101, 14812-14817. https://doi.org/10.1073/pnas.0406166101

Hlaing, T., Tun-lin, W., Somboon, P., Socheat, D., Setha, T., Min, S., Chang, M.S., \& Walton, C. (2009). Mitochondrial pseudogenes in the nuclear genome of Aedes aegypti mosquitoes: implications for past and future population genetic studies. $B M C$ Genetics, 10, 11. https://doi.org/10.1186/14712156-10-11

Hrcek, J., Miller, S.E., Quicke, D.L.J., \& Smith, M.A. (2011). Molecular detection of trophic links in a complex insect host-parasitoid food web. Molecular Ecological Resources, 11(5), 786-94. https://doi.org/10.1111/j.1755-0998.2011.03016.x 
Insect Barcode Informatica (IBIn). - Indian council of Agricultural Research, National Bureau of Agricultural Insect Resources. Available from http://www.cib.res.in/ibin/index.php (accessed on 30 July 2017)

Ivanova, N.V., Borisenko, A.V., \& Hebert, P.D.N. (2009). Express barcodes: racing from specimen to identification. Molecular Ecological Resources, 9, 35- $\quad 41 . \quad$ https://doi.org/10.1111/j.17550998.2009.02630.x

Jalali, S.K., Ojha, R., Venkatesan, T., \& Chakravarthy, A.K. (2015). DNA Barcoding for Identification of Agriculturally Important Insects. New Horizons in Insect Science: Towards Sustainable Pest Management: Springer, India, pp. 13-23. https://doi.org/10.1007/978-81-322-2089-3_2

Jarman, S.N. \& Elliott, N.G. (2000). DNA evidence for morphological and cryptic Cenozoic speciations in the Anaspididae, 'living fossils' from the Triassic. Journal of Evolution Biology, 1(3), 624-633. https://doi.org/10.1046/j.1420-9101.2000.00207.x

Jinbo U., Kato T., \& Ito M. (2011). Current progress in DNA barcoding and future implications for entomology. Entomological Science, 14, 107-124. https://doi.org/10.1111/j.1479-8298.2011.00449.x

Jurado-Rivera, J.A., Vogler, A.P., Reid, C.A.M., Petitpierre, E., \& Gomez-Zurita, J. (2009). DNA barcoding insect-host plant associations. Proceedings of the Royal Society of London B: Biological Sciences, 276, 639-648. https://doi.org/10.1098/rspb.2008.1264

Kerr, K.C.R., Stoeckle, M.Y., Dove, C.J., Weigt, L.A., Francis, C.M., \& Hebert, P.D.N. (2007). Comprehensive DNA barcode coverage of North American birds. Molecular Ecology Notes, 7, 535543. https://doi.org/10.1111/j.14718286.2007.01670.x

Kumara, G.A., Venkatesana Stouthamerb, R., Niranjanaa, P., Lalithaa, Y., \& Jalalia, S.K. (2009). Internal transcribed spacer-2 restriction fragment length polymorphism (ITS-2-RFLP) tool to differentiate some exotic and indigenous trichogrammatid egg parasitoids in India. Biological Control, 49 (3), 207-213. https://doi.org/10.1016/j.biocontrol.2009.02.010

Lee, W., Kim, H., Lim, J., Choi, H.R., Kim, Y., Kim, Y.S., Ji, J.Y., Foottit, R.G., \& Lee, S. (2010). Barcoding aphids (Hemiptera:Aphididae) of the Korean Peninsula: updating the global data set. Molecular Ecological Resources, 11 (1), 32-7. https://doi.org/10.1111/j.1755-0998.2010.02877.x

Lukhtanov, V.A., Sourakov, A., Zakharov, E.V., \& Hebert, P.D.N. (2009). DNA barcoding Central
Asian butterflies: increasing geographical dimension does not significantly reduce the success of species identification. Molecular Ecological. Resources, 9 , 1302-1310. https://doi.org/10.1111/j.1755-0998.2009.02577.x

Mayhew, P.J. (2007.). "Why there are so many insect species? Perspectives from fossils and Phylogenies". Biological Reviews, 82 (3), 425-454. https://doi.org/10.1111/j.1469-185X.2007.00018.x

Miller, K.B., Alarie, Y., Wolfe, G.W., \& Whiting, M.F. (2005). Association of insect life stages using DNA sequences: the larvae of Philodytes umbrinus (Motschulsky) (Coleoptera: Dytiscidae). Systematic Entomology, 30, 499-509. https://doi.org/10.1111/j.1365-3113.2005.00320.x

Munro, J.B., Heraty, J.M., Burks, R.A., Hawks, D., Mottern, J., Cruaud, A., Rasplus, J.Y., \& Jansta, P. (2011). A Molecular Phylogeny of the Chalcidoidea (Hymenoptera), PLoS One, 6 (11), e27023. https://doi.org/10.1371/journal.pone.0027023

Padial, J.M., \& Riva, I.D.L. (2007). Integrative taxonomists should use and produce DNA barcodes. Magnolia Press Zootaxa, 1586, 67-68.

Pfenninger, M., Nowak, C., Kley, C., Steinke, D., \& Streit, B. (2007). Utility of DNA taxonomy and barcoding for the inference of larval community structure in morphologically cryptic Chironomus (Diptera) species. Molecular Ecology, 16 (9), 195768. https://doi.org/10.1111/j.1365294X.2006.03136.x

Pinzon-Navarro, S., Jurado-Rivera, J.A., Gomez-Zurita, J., Lyal, C.H.C., \& Vogler, A.P. (2010). DNA profiling of host-herbivore interactions in tropical forests. Systematic Entomology, 35 (Suppl 1), 1832.

Pires, A.C., \& Marinoni, L. (2010). DNA barcoding and traditional taxonomy unified through Integrative Taxonomy: a view that challenges the debate questioning both methodologies. Biota Neotropica, 10 (2), 339-346. https://doi.org/10.1590/S167606032010000200035

Plaisance, L., Caley, M. J., Borisenko, A.V., Sones, J.E., \& Hebert, P.D.N. (2009). The front-end logistics of DNA barcoding: challenges and prospects. Molecular Ecological Resources, 9, 2734. https://doi.org/10.1111/j.17550998.2009.02629.x

Pratheepa, M., Jalali, S.K., Arokiaraj, R.S., Venkatesan, T., Panda, M.N.M., \& Pattar, S. (2014). Insect Barcode Information System Volume: Bioinformation, $\quad$ 10(2), 98-100. https://doi.org/10.6026/97320630010098 
Preethi, N., Lakshmi, P., \& Menon, D. (2016). Diversity and Distribution of Chalcid Wasps in Kerala: Key Biological Control Agents in Cultivated Ecosystems. Arthropod Diversity and Conservation in the Tropics and Sub-tropics, Springer Singapore, pp. 213-226. https://doi.org/10.1007/978-981-101518-2_13

Ratnasingham, S., \& Hebert, P.D.N. (2007). BOLD: The Barcode of Life Data System. Molecular Ecological Notes, 7, 355-64. Available from (http://www.barcodinglife.org). https://doi.org/10.1111/j.1471-8286.2007.01678.x

Raupach, M.J., Astrin, J.J., Hanning, K., Peters, M.K., Stoeckle, M.Y., \& Wägele, J.W. (2010). Molecular species identification of Central European ground beetles (Coleoptera: Carabidae) using nuclear rDNA expansion segments and DNA barcodes. Frontiers in Zoology, 7(1), 26. https://doi.org/10.1186/1742-9994-7-26

Rivera, J., \& Currie, D.C. (2009). Identification of Nearctic black flies using DNA Barcodes (Diptera: Simuliidae). Molecular Ecological Resources, 9, 224-236. 0998.2009.02648.x

Rubinoff, D., Cameron, S., \& Will, K. (2006). A genomic perspective on the shortcomings of mitochondrial DNA for "barcoding" identification. Journal of Heredity, 97(6), 581-594. https://doi.org/10.1093/jhered/es1036

Salokannel, J., Rantala, M.J., \& Whalberg, N. (2010). DNA-barcoding clarifies species definitions of Finnish Apatania (Trichoptera: Apataniidae). Entomologica Fennica, 21, 1-11.

Savolainen, V., Cowan, R.S., Vogler, A.P., Roderick, G.K., \& Lane, R. (2005). Towards writing the encyclopedia of life: an introduction to DNA barcoding. Philosophical Transactions of the Royal Society B. Biological Sciences, 360, 1805-1811. https://doi.org/10.1098/rstb.2005.1730

Sheffield, K.A., Hebert, P.D.N., Kevan, P.G., \& Packer, L. (2009). DNA Barcoding a regional bee (Hymenoptera: Apoidea) fauna and its potential for ecological studies. Molecular Ecological Resources, 9, 196-207. https://doi.org/10.1111/j.1755-0998.2009.02645.x

Shufran, K.A., \& Puterka, G.J. (2011). DNA Barcoding to Identify All Life Stages of Holocyclic Cereal Aphids (Hemiptera: Aphididae) on Wheat and Other Poaceae. Annals of the Entomological Society of America, 104, 39-42. https://doi.org/10.1603/AN10129
Sithanantham, S., Chandish, R.B., Jalali, S.K., \& Bakthavatsalam, N. Molecular Taxonomy of Trichogammatids . Biological control of insect pests using egg parasitoids., 1, 39-66.

Smith, M.A, Fernandez-Triana, J., Roughley, R., \& Hebert, P.D.N. (2009). DNA barcode accumulation curves for understudied taxa and areas. Molecular Ecological Resources, 9, 208-216. https://doi.org/10.1111/j.1755-0998.2009.02646.x

Smith, M.A., Fisher, B.L., \& Hebert, P.D.N. (2005). DNA barcoding for effective biodiversity assessment of a hyperdiverse arthropod group: the ants of Madagascar. Philosophical Transactions of the Royal Society B. Biological Sciences, 360, 1825-1834. https://doi.org/10.1098/rstb.2005.1714

Smith, M.A., Woodley, N.E., Janzen, D.H., Hallwachs, W., \& Hebert, P.D.N. (2006). DNA barcodes reveal cryptic host-specificity within the presumed polyphagous members of a genus of parasitoid flies (Diptera: Tachinidae). Proceedings of the National Acadamy of Sciences, USA, 103, 3657-3662. https://doi.org/10.1073/pnas.0511318103

Song, H., Buhay, J. E., Whiting, M. F., \& Crandall, K. A. (2008). Many species in one: DNA barcoding overestimates the number of species when nuclear mitochondrial pseudogenes are coamplified. Proceedings of the national academy of sciences, 105(36), 13486-13491. https://doi.org/10.1073/pnas.0803076105

Strutzenberger, P., Brehm, G., \& Fiedler, K. (2010). DNA barcoding-based species delimitation increases species count of Eois (Geometridae) moths in a well-studied tropical mountain forest by up to $50 \%$. Insect Science, 18, 349-362. https://doi.org/10.1111/j.1744-7917.2010.01366.x

Tautz, D., Arctander P., Minelli, A., Thomas, R.H., \& Vogler, A.P. (2003). A plea for DNA taxonomy. Trends in Ecology and Evolution, 18, 70-74. https://doi.org/10.1016/S0169-5347(02)00041-1

Theron, J., \& Cloete, T.E. (2000). Molecular techniques for determining microbial diversity and community structure in natural environments. Critical Reviews in Microbiology, 26, 37-57. https://doi.org/10.1080/10408410091154174

Vaglia, T., Haxaire, J., Kitching, I.J., Meusnier, I., \& Rougerie, R. (2008). Morphology and DNA barcoding reveal three cryptic species within the Xylophanes neoptolemus and loelia species-groups (Lepidoptera: Sphingidae). Zootaxa, 1923, 18-36.

Venkatesan, T., Prabhakar, R., Baskar, R., Jalalia, S.K., \& Lalitha, C.R. (2016). Differentiation of some indigenous and exotic trichogrammatids 
(Hymenoptera: Trichogrammatidae) from India based on Internal transcribed spacer-2 and cytochrome oxidase-I markers and their phylogenetic relationship. Biological Control, 101, 130-137.

https://doi.org/10.1016/j.biocontrol.2016.07.005

Ward, R.D., Zemlak, T.S., Innes, B.H., Last P.R., \& Hebert, P.D.N. (2005). DNA barcoding of Australia's fish species. Philosophical Transactions of the Royal Society B. Biological Sciences, 360, 1847-1857. https://doi.org/10.1098/rstb.2005.1716

Wheat, C.W., \& Watt, W.B. (2008). A mitochondrialDNA-based phylogeny for some evolutionarygenetic model species of Colias butterflies (Lepidoptera: Pieridae). Molecular Phylogenetics and Evolution, 47, 893-902. https://doi.org/10.1016/j.ympev.2008.03.013

Wiemers, M., \& Fiedler, K. (2007). Does the DNA barcoding gap exist?-a case study in blue butterflies (Lepidoptera: Lycaenidae). Frontiers in zoology, 4(1), $\quad 8$. https://doi.org/10.1186/17429994-4-8

Williams, S.T., \& Knowlton, N. (2001). Mitochondrial pseudogenes are pervasive and often insidious in the snapping shrimp Genus Alpheus. Molecular Biology and Evolution, 18, 1484-1493. https://doi.org/10.1093/oxfordjournals.molbev.a003 934

Yoshitake, H., Kato, T., Jinbo, U., \& Ito, M. (2008). A new Wagnerinus (Coleoptera: Curculionidae) from northern Japan: description including a DNA barcode. Zootaxa, 1740, 15-27.

Zhang, D. X., \& Hewitt, G. M. (1996). Nuclear integrations: challenges for mitochondrial DNA markers. Trends in Ecology \& Evolution, 11(6), 247-251. https://doi.org/10.1016/01695347(96)10031-8

Zhou, X., Robinson, J.L., Geraci, C.J., Parker, C.R., Flint, J.R.O.S., Etnier, D.A., Ruiter, D., Dewalt, R.E., Jacobus, L.M., \& Hebert, P.D.N. (2011). Accelerated construction of a regional DNAbarcode reference library: caddisflies (Trichoptera) in the great smoky mountains national park. Journal of the North American Benthological Society, 30, 131-162. https://doi.org/10.1899/10010.1 